\section{Kulyk V., Burykin 0., Pirnyak V.}

\title{
OPTIMIZATION OF THE PLACEMENT OF REACTIVE POWER SOURCES IN THE ELECTRIC GRID BASED ON MODELING OF ITS IDEAL MODES
}

Роботу присвячено розв'язанню задачі оптимізації перетікань реактивної енергї у електричних мережах (EM) енергопостачальних компаній (ЕК). Об'єктом дослідження є процес транспортування та розподілу електроенергї електричними мережами ЕК. Предмет дослідження - методи та засоби оптимізації перетікань реактивної енергї у таких мережах. Одним з найбільш проблемних місць експлуатації ЕМ $\epsilon$ забезпечення їх енергоефективності в умовах постійної зміни споживання та генерування електроенергї. Відомо, що найбільш дієвим заходом для зменшення втрат електроенергї в ЕМ є запровадження заходів з оптимізації перетікань реактивної енергії. Однак для оптимізації розміщення додаткових джерел реактивної потужності (ДРП) необхідно розв'язувати задачі нелінійної багатофакторної оптимізації, що пов'язано з низкою проблем.

На підставі досліджень показано, що для оптимізації розміщення ДРП доцільно використовувати результати моделювання «ідеальних» режимів ЕМ за реактивною потужністю на підставі заступних схем з активними опорами. Економічні витрати, пов'язані з встановленням та експлуатацією ДРП, запропоновано перераховувати у відповідні економічні опори заступної схеми ЕМ. Розроблено математичні співвідношення для економічних опорів встановлених ДРП, а також таких, що підлягають встановленню за результатами розв'язання оптимізаційної задачі.

Застосування такого підходу, на відміну від класичних методів, істотно скорочує тривалість розрахунків та дозволяє отримати розв'язок, наближений до глобального мінімуму виробничих витрат. Обчислювальна ефективність та надійність підходу забезпечується зведенням задачі багатофакторної оптимізації перетікань реактивної енергї у проектній постановиі до ітеративного розрахунку «ідеального» режиму ЕМ за відповідними заступними схемами та навантаженнями.

Програмна реалізація дозволила підтвердити ефективність запропонованого підходу для низки практичних задач. Показано, що отримані рішення з оптимізації розміщення ДРП у розподільних мережах наближають рентабельність капіталовкладень до глобального максимуму незалежно від розмірності задачі та переліку обмежень на параметри.

Ключові слова: електрична мережа, «ідеальний» режим, перетікання реактивної енергї, багатофакторна оптимізація, джерело реактивної потужності.

\section{Introduction}

Modern electric grids (EG) of energy supply companies (EC) should provide reliable and efficient energy supply to consumers, as well as transportation of distributed energy sources (DES). In addition to the EG reconstruction and the modernization of their main equipment, they acquire the urgency of research in the direction of improving the structure and methods of managing their modes [1].

To solve this problem, the principles of building modern electric power systems must correspond to the general progress of technics and technology [2]. This can be achieved by introducing, together with new information technologies, the results of system-based theoretical studies of the EGs, based on fundamental physical principles in combination with modern approaches to mathematical modeling and optimization of their states [3].

Optimizing the levels of local generation of reactive energy in modern electric grids (EG) in combination with informatization and ensuring their manageability, allows to reduce the technological costs of electricity, regardless of changes in the EG load. The tasks of improving the structure and parameters of EG should be solved in such way that the formation of design solutions, in particular the connection and operation of reactive power sources (RPS), which is linked to the effective operation of existing electric units. The maximum effect here can be achieved by optimizing the RPS location and parameters, taking into account changes in the nature of power consumption, as well as DES modes, the number and power of which is constantly growing. Proceeding from this, in modern conditions the setting of optimization problems related to the distribution of reactive energy, as well as their dimensionality, is changing. This can lead to ineffectiveness of classical methods for their solution.

An alternative is placement of the RPSs and optimization of their parameters in order to bring the state of the electric grid closer to the «ideal» one for power losses [3]. This approach has advantages over traditional optimization methods. However, in order to determine the optimal solutions, it is necessary to take into account the peculiarities of the RPS disposition in the «ideal» EG state model, as well as economic factors. 
Proceeding from this, the paper shows the possibility and investigates the features of optimizing the flow of reactive energy in electric grids of EC based on the principle of least action in the formulation of the Hamilton-Ostrogradsky (PLA). The use of PLA makes it possible to obtain a new method for optimizing the location of reactive power sources in electric grids by the criteria of minimum energy losses and the maximum return on investment.

\section{The object of research and its technological audit}

The object of research is the process of transportation and distribution of electricity by electric grids of power supply companies.

The work deals with distribution EGs with rated voltage 220-10 (6) $\mathrm{kV}$, intended for the transportation of electric power from the boundary of the balance belonging of ECs (buses of system substations) to final consumers, or substitute substations. In addition, they provide transportation of electricity generated by local energy sources, in particular renewable, to the EC balance sheet. The load on electric grids is uneven, and the operating modes are unstable. On this basis, the process of electricity transmission by grids is dynamic with a significant stochastic component.

The main equipment of the electric grids is worn out at $80 \%$, and its parameters do not correspond to modern operating conditions. The lack of means for monitoring the mode parameters, especially in $35 \mathrm{kV}$ or lower grids, makes it difficult to solve operational problems. On this basis, the EG functioning is often ineffective.

The quality of electricity supply and power losses in EGs indirectly characterizes the level of EC management and, finally, the profitability of the company. Therefore, reducing losses and ensuring the quality of electricity is one of the most problematic locations for EG operation. Experience shows that the most profitable activity here is the optimization of the flow of reactive energy with the help of RPS. However, its implementation requires a preliminary solution of the problem of non-linear multifactor optimization in the field of constraints on dependent parameters, which is associated with a number of problems.

\section{The aim and objectives of research}

The aim of research is creation of prerequisites for increasing the efficiency of the EG functioning with distributed generation by developing a method and algorithms for optimizing the placement of additional RPSs.

To achieve this aim, it is necessary to solve the following tasks:

1. To analyze the optimization of the flow of reactive energy in the EG and the known methods for their solution.

2. To justify the expediency of using the «ideal» modes for energy losses to optimize the location of the RPS in electric grids.

3. To develop a method for determining and adjusting the economic resistance of the RPS, which allows to take into account in the model of the «ideal» EG mode the economic costs associated with the establishment of such sources.

4. To conduct a full-scale experiment to confirm the effectiveness of the proposed approach and the developed optimization algorithms.

\section{Research of existing solutions of the problem}

A feature of optimization of reactive flows in modern electric systems is that in addition to traditional sources of reactive energy (electric stations, specialized devices, transmission lines), distributed energy sources (DES) are being introduced here [4]. DES functioning is determined by the influence of the environment and depends little on the restrictions imposed by the operation in electric grids. Using synchronous and asynchronous generators, as well as inverter converters, these sources can generate or consume reactive energy, depending on the mode of operation. As a result, periodically there are reverse flows that affect the reliability and efficiency of electricity transportation.

As the pace of development of renewable energy, and therefore the DES grows annually, this problem will only worsen. This is evidenced by the experience of Western countries.

Thus, in [5], using the German power system as an example, it is shown that the generation of the reactive power of the DES must be manageable and correspond to the EG mode. This will facilitate the exchange of reactive energy between distribution and transmission grids and maintaining voltage stability. The decentralization of energy systems requires that the DES takes greater responsibility for problems in EG.

In [6] it is noted that the DES power can cause unacceptable increases in voltage levels in distribution grids, in particular because the grid equipment required to connect the DES generates additional reactive power. However, using the reactive power management of the DES, the operators of distribution grids can solve these problems.

In work [7] it is noted that in Italy an important factor of influence on the modes of distribution grids, in particular jet flows and voltage levels, is the growing demand for electric vehicles. According to the research results, the main requirements for distribution grid operators are proposed, which are made when assessing the technical conditions for connecting equipment for fast charging of electric vehicles to existing low-voltage distribution grids.

In work [8] the technique of an estimation of tendencies of power consumption in electric systems with DES is offered. It is shown that on the links between the transmission and distribution grids in the UK and other European countries during periods of minimal load, the demand for reactive power will continue to decline. This is considered as one of the factors that pose new problems in backbone grids in maintaining specified voltage levels.

Proceeding from this, the draft standard «Determination of the necessary conditions and algorithms for accounting wind and solar power plants in the setting up of emergency control devices designed to prevent stability violations (CDSV) in the sections of UES of Ukraine. Methodical recommendations», certain levers of centralized influence on the DES work are laid.

However, changes in the structure of generation and power consumption, especially reactive energy, have practically not been reflected in the existing normative documents on the development of measures to reduce losses in the electric grids of the UES. Thus, methods and means of optimizing project solutions in this direction need to be improved. 
To solve the problems associated with optimizing the levels of reactive power compensation in electric grids using a complex criterion, methods of decomposition, linear and nonlinear programming have traditionally found application [9, 10]. However, due to the use of assumptions and simplifications, such methods can direct the process of decoupling to local extremes.

In a number of works, in particular [10, 11], the expediency of the transition from the problem of complex optimization of the flow of reactive power to the EG, to the complex of optimization tasks for individual stages of RPS implementation is substantiated. It is shown that this makes it possible to apply classical optimization methods [10] practically without deterioration of adequacy. However, this approach is accompanied by the need for additional assumptions at the stage of decomposition. In addition, the coordination of solutions of particular problems for a complex system with distributed generation turns into a rather complex optimization problem [12]. This reduces the reliability and speed of obtaining a decoupling approaching the global optimum, worsening the efficiency of design decisions and operational management [12].

The modern development of information technologies and computing facilities forms prerequisites for the application of other approaches to solving problems of optimizing the flow of reactive energy, oriented, in particular, to the automation of the EG functioning. Proceeding from this, recently elements of artificial intelligence [12-15], in particular artificial neural grids [13], expert systems [6], genetic algorithms [14] and evolutionary programming [15] are actively used. However, excessive consumption of time in the case of using evolutionary and genetic algorithms for finding optimal solutions limits their use in energy systems, especially for real-time problems [12].

To solve the problems of optimization of power flows in the electric grids with the DES, in contrast to the optimized selection of options, to which the above methods relate, it is advisable to apply a comprehensive approach based on the principle of least action. In particular, it is shown in [3] that the PLA allows to eliminate the problem of low reliability and speed of the search for optimal solutions. A positive result gives a change in the direction of the search, which starts not from an arbitrary initial approximation, but from an extreme value, which corresponds to the «ideal» mode of the system by the energy criterion. However, for the analytical determination of the coordinates of the mode, it corresponds to the Euler-Lagrange equation [3] in the state space for given independent variables, it is necessary to correct the calculated model of the system in a certain way depen- ding on the list of optimized variables and the optimality criterion.

\section{Methods of research}

The principle of least action in the formulation of Hamilton-Ostrogradsky was used to solve the posed problems. To simulate steady-state EG modes, the nodal stress method is used. To develop algorithms and programs, object-oriented analysis is applied.

According to the principle of least action, the current state of EG, as a technical system, at an arbitrary moment of time corresponds to a global minimum of energy loss, the value of which corresponds to the level of organization of the system. However, this situation often does not correspond to economic criteria or restriction on the mode parameters [3], that is, it requires an appropriate correction.

According to the PLA, the search for the optimal mode for the UES is determination of the «ideal» mode, which corresponds to the minimum possible losses of electricity for a given set of independent system parameters. Further, by imposing active restrictions on the parameters of the mode, it reduces to the optimal from the admissible range of values. Active restrictions always cause an increase in electricity losses in the optimal UES modes in comparison with the «ideal» [3].

It is known from [16] that the task of optimizing the distribution of the load between the RPS in electric grids by the criterion of the minimum energy loss can be reduced to the calculation of the «ideal» or economic distribution in the EG using the equivalent $r$-circuit.

A similar approach can be applied to optimize the RPS placement and power in electric grids with a complex technical and economic criterion. For this purpose, additional economic supports (Fig. 1) reproducing the influence of economic factors, including the RPS cost and the costs of their operation, are introduced into the equivalent $r$-circuit. Introduction of the installed capacities of additional RPSs in the list of dependent parameters of the EG mode allows to calculate their optimal values. The optimal values correspond to the minimum active power loss in the calculation circuit with the economic supports, and hence the minimum cost associated with the RPS installation and operation.

The peculiarity of the proposed approach is the method of determining economic resistances for the RPS representation introduced into the interventions of the EG equivalent $r$-circuit to account for their technical and economic indicators.

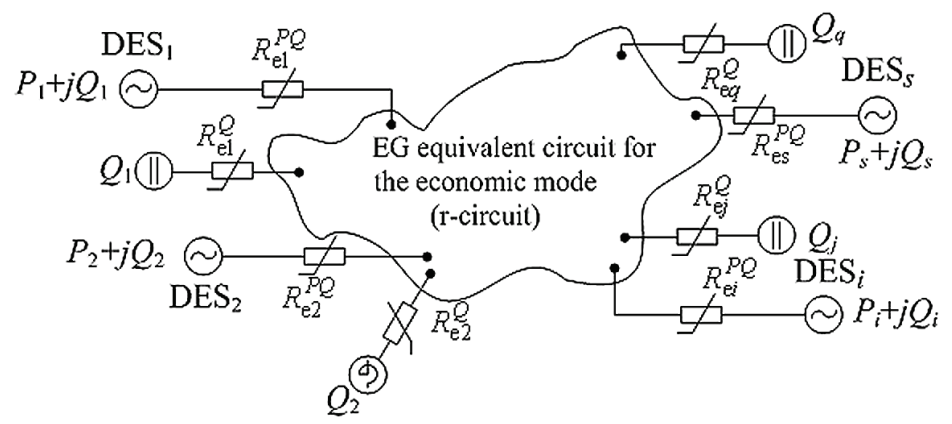

Fig. 1. Equivalent circuit of the electric grid for calculating the «ideal» mode by the economic criterion 


\section{Research results}

6.1. Determination of RPS economic resistance for solving operational problems. In the simplest case [3], for the assumption that the generation of reactive power in the EG is not associated with any costs $\beta_{i}\left(Q_{i}\right)=0$, the purpose of placing additional RPSs and optimally adjusting their reactive power may be to reduce the power losses in the EG. If assume that the active power $P_{i}$ for a given time is given and unchanged, then the losses depend only on the overflows of the reactive power. The task of optimizing the EG mode for reactive power can be represented as the task of minimizing the losses of active power [17]:

$$
V_{Q}=f(Q, U) \rightarrow \min ,
$$

in the conditions of the balance of reactive power in the system:

$$
G=\sum_{j=1}^{n_{p q}} Q_{j}+\sum_{i=1}^{n_{q}} Q_{i}-\sum Q_{l}-\Delta Q\left(Q_{i}\right)=0
$$

where $\sum_{j=1}^{n_{p q}} Q_{j}, \sum_{i=1}^{n_{q}} Q_{i}-$ total generation of reactive power by EG power sources in the amount $n_{p q}$ and DES in the amount $n_{q}$, respectively; $\sum Q_{l}$ - total load, the value of which is set; $\Delta Q\left(Q_{i}\right)$ - loss of reactive power in EG elements.

The classical condition for the optimality of the RPS power can be obtained by the Lagrange method [17]

$$
\frac{\partial V_{Q} / \partial Q_{i}}{1-\partial \Delta Q / \partial Q_{i}}=i d e m
$$

A similar result can be obtained by minimizing the loss of active power for a given EG mode in which the costs of RPS operation are taken into account by the corresponding economic supports [3].

If submit specific costs for the RPS operation in the form of a cost characteristic $\beta_{i}\left(Q_{i}\right)$, reduced to $1 \mathrm{kvar}$ of reactive power, the total costs for the period $T$ :

$$
B_{Q i}=\beta_{i}\left(Q_{i}\right) Q_{i} T \text {. }
$$

To recalculate the costs (4) to the economic resistance, these costs are equated to the cost of electricity losses from reactive power flows in the EG branch with a $R_{e i}^{Q}$ in the time-interval $T$ with a conditionally constant load:

$$
B_{Q i}=V_{Q i} T c=\frac{Q_{i}^{2}}{U_{i}^{2}} R_{e i}^{Q} T c,
$$

where $Q_{i}$ and $U_{i}$ - respectively, the flow of reactive power and voltage at the beginning of the branch; $c$ - the cost of electricity losses. Whence

$$
R_{\mathrm{e} i}^{Q}=\frac{\beta_{i}\left(Q_{i}\right) U_{i}^{2}}{Q_{i} \cdot c} .
$$

If the sources of reactive power are placed by economic resistances $R_{\mathrm{e} i}^{Q}$ (Fig. 1), then it is possible to replace the definition of operating costs by the calculation of current distribution and electric power losses in the equivalent r-circuit of the EG. The calculated current distribution will correspond to a minimum of the costs for generating RPS reactive power and compensation of electric energy losses in the EG during the period $T$.

To confirm the task of optimizing the flow of reactive power in EG by the criterion of minimum operating costs can be represented as follows:

$$
V_{Q \Sigma}=V_{Q}+\sum_{i=1}^{n_{q}} 3 R_{\mathrm{ei}}^{Q} I_{i}^{2} \rightarrow \min
$$

in conditions of the balance of reactive power in the system (2).

The Lagrange function for (7) after substituting the values of economic resistances according to (6) will have the form:

$$
L=V_{Q}+\sum_{i=1}^{n_{q}} \frac{\beta_{i}}{c} Q_{i}+\lambda G
$$

After differentiation, a classical condition for the optimal load distribution between the RPSs based on the minimum operating cost criterion is obtained [17]:

$$
\frac{\partial V_{Q} / \partial Q_{i}+\beta_{i} / c}{1-\partial \Delta Q / \partial Q_{i}}=i d e m .
$$

The optimality condition of the RPS load is obtained taking into account the operating costs $\beta_{i}$ and assuming that the latter, together with the cost of electric energy losses, are constant over a time interval $T$, i. e., $\beta_{i} / c=$ const. Proceeding from this, the optimal RPS power, which are determined by (8) and (3), naturally differ. If the costs of operating the RPS are not taken into account $\left(\beta_{i}=0\right)$, then conditions (3) and (8) coincide. Thus, it is shown that the problem of optimizing the RPS generation in electric grids by economic criteria can be reduced to the calculation of the steady-state mode of EG by the equivalent $r$-circuit. In it, the costs of RPS operation are represented by non-linear economic supports. The value of the latter depends on the optimality criterion and the list of independent optimized variables.

6.2. Determination of RPS economic resistance for solving project tasks. According to the normative document GKD 340.000.002-97, the main criterion for the effectiveness of design solutions in the power industry is the return on investment:

$$
R_{i}=\frac{P_{a}+A_{r}}{K},
$$

where $P_{a}=P_{b}-T_{i}-C_{\text {loan }}-$ the current profit; $P_{b}=A-B_{e}-B_{l}-A_{r}-$ balance sheet annual profit; $A=\left(V_{Q 0}-V_{Q}\right) \tau c$ - additional annual profit, due to the reduction of electricity losses due to the RPS establishment; $C_{e}=\alpha_{e} K-$ annual operating costs for RPS; $C_{l}=\alpha_{l} \tau A \sum_{i=1}^{n_{q}} Q_{i}$ - the cost of electricity losses in the RPS; $A_{r}=\alpha_{r} K$ - additional annual depreciation charges for renovation; $T_{i}=\alpha_{i} P_{b}$ - income tax; $C_{\text {loan }}=\alpha_{\text {loan }} K-$ annual costs for loan servicing; $K=\sum_{i=1}^{n_{q}} K_{i}$ - investment for the RPS introduction; $V_{Q 0}$ - power losses in the characteristic EG mode to the establishment of additional RPS; $\tau$ - the maximum loss time. 
After substitution and simple transformations, expression (8) can be represented as:

$$
\begin{aligned}
& R_{i}=V_{Q 0} \tau \frac{c}{K}-V_{Q} \tau\left(1-\alpha_{i}\right) \frac{c}{K}- \\
& -\left(\alpha_{e}+\alpha_{l} \sum_{i=1}^{n_{q}} Q_{i} \tau \frac{A}{K}+\alpha_{r}\right)\left(1-\alpha_{i}\right)-\alpha_{\text {loan }}-\alpha_{r} .
\end{aligned}
$$

If, on individual calculation iteration, by artificially limiting the increment of $Q_{i}$ capacity, the capital investment in RPS is conditionally assumed to be constant, then the first component of expression (9) will practically not affect the optimal power values of the RPS for this iteration. So, the task of finding the maximum profitability $R_{i}$ can be reduced to an iterative search for a minimum of the function of relative operating costs in EG with the restriction of incremental power of additional RPSs:

$$
\begin{aligned}
& B_{*}=V_{Q} \tau\left(1-\alpha_{i}\right) \frac{c}{K}+ \\
& +\left(\alpha_{e}+\alpha_{l} \sum_{i=1}^{n_{q}} Q_{i} \tau \frac{A}{K}+\alpha_{r}\right)\left(1-\alpha_{i}\right)+\alpha_{\text {loan }}+\alpha_{r} \rightarrow \min .
\end{aligned}
$$

Taking into account the assumed assumption, expression (10) can be divided into a conditionally constant coefficient $b_{l}=\tau\left(1-\alpha_{i}\right) \frac{c}{K}$, which practically does not affect the solution of the problem. Thus, the function of equivalent power losses in EG after the installation of additional RPS is obtained. Its minimization in the field of balance constraints (2) and constraints on parameters with sequential refinement of capital investments $K$ will allow obtaining values of capacities $Q_{i}$, close to the solutions of the maximization of profitability problem (8):

$$
\begin{aligned}
& V_{Q e q}=V_{Q}+\alpha_{l} \sum_{i=1}^{n_{q}} Q_{i}+ \\
& +\sum_{i=1}^{n_{q}} K_{i} \frac{\left(\alpha_{e}+\alpha_{r}\right)\left(1-\alpha_{i}\right)+\left(\alpha_{\text {loan }}+\alpha_{r}\right)}{\tau c\left(1-\alpha_{i}\right)} \rightarrow \text { min. }
\end{aligned}
$$

Taking into account equivalent circuit for determining the parameters of the «ideal» mode of additional losses $V_{\text {add }}=V_{\text {Qeq }}-V_{Q}$ associated with the RPS establishment and operation, in accordance with (5), (6), the corresponding economic supports are determined:

$$
R_{e i}^{Q}=\frac{U_{i}^{2}}{Q_{i}}\left[\alpha_{l}+\frac{K_{i}}{Q_{i}} \frac{\left(\alpha_{e}+\alpha_{r}\right)\left(1-\alpha_{i}\right)+\left(\alpha_{\text {loan }}+\alpha_{r}\right)}{\tau c\left(1-\alpha_{i}\right)}\right],
$$

The ratio for determining economic resistances $R_{e i}^{Q}$ contains independent $\left(Q_{i}\right)$ and dependent $\left(U_{i}\right)$ parameters of the optimization task, as well as economic indicators $\left(K_{i}\right)$, which will change during the search for the denouement. So these supports are not permanent (Fig. 2) and need to be refined at each iteration.

From the shown graphs (Fig. 2) it is clear that the value of economic resistances is commensurate with the values of the resistances of power lines and transformers of distribution grids.

The sensitivity of economic resistances to voltage deviations that arise as a result of the RPS operation is significantly reduced with the increase in the installed capacity of the last $Q_{i}$. At the same time, the values decrease $R_{e i}^{Q}$. This contributes to the further increase in the installed capacity of the RPS, and as a result - to reduce the number of installed devices, and consequently, to reduce capital costs and operating costs.

Thus, the solution of the problem of optimizing the RPS location in the statement (7) using the economic resistances (12) ensures the achievement of maximum profitability (8).

When solving the problem of optimizing the distribution of EG reactive loads between reactive energy sources, it should be borne in mind that electric power stations (ES), in particular dispersed energy sources, can be considered as such sources. The latter, together with the generation of active power $P_{i}$, perform for the power system a system service to ensure the balance of reactive power and voltage regulation. In this case, the power plant will reduce the electricity production from generating excessive reactive power, in comparison with technological necessity, that is, incurring losses.

Their cost can be estimated as follows:

$$
B_{Q i}=\beta_{P i} P_{n p i}\left(Q_{i}\right) T,
$$

where $\beta_{P i}$ - the price of electricity $i$-th source, that is the cost of $1 \mathrm{~kW} \cdot \mathrm{h}$ of electricity released from the bus at a given capacity $P_{i} ; P_{n p i}\left(Q_{i}\right)$ - the active power of the $i$-th EG in the time interval $T$ is underdeveloped, is due to the generation of additional reactive power $Q_{i}$.

By analogy between (5) and (13), the economic resistance, the cost of electricity losses in which is equivalent to the EG losses associated with the production of reactive power at the station, can be determined by the formula:

$$
R_{e i}^{Q}=\frac{\beta_{P i} P_{n p i}\left(Q_{i}\right) U_{i}^{2}}{Q_{i}^{2} c} .
$$

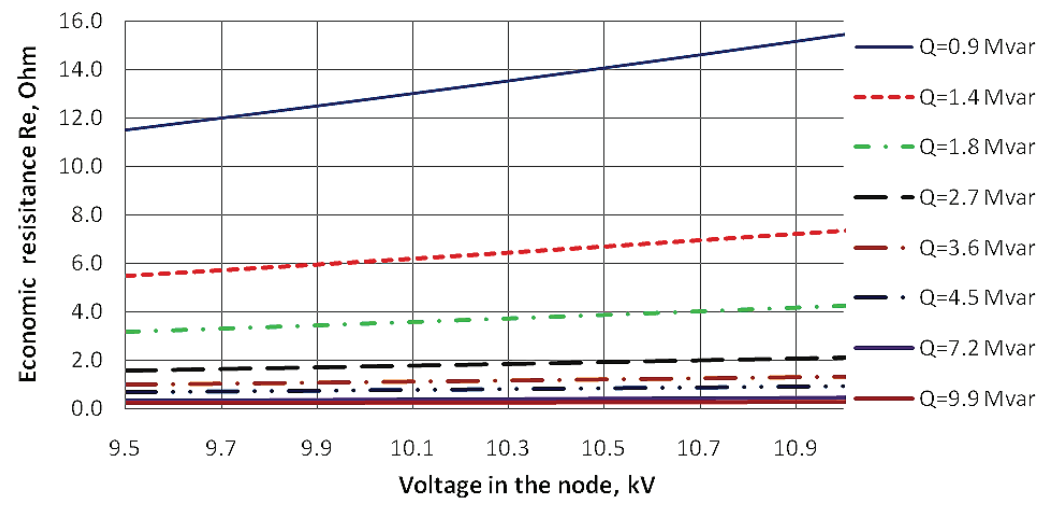

Fig. 2. The value of economic resistances, calculated for reactive power compensation facilities with a nominal voltage of $10 \mathrm{kV}$ 
In expression (14) there are no coefficients characterizing depreciation charges, profit taxes and other economic factors, since they are classified as primary activity, and the task of optimizing the generation of reactive power is considered as an auxiliary service. Proceeding from (14), power plants, in particular the DESs, generating reactive power to form a EG balance, can increase their profits, especially when, due to the influence of independent factors limiting the flow of primary energy, the amount of electricity generation decreases.

If the power plant performs, in addition to generating electricity, a system function to ensure the balance of reactive power and voltage regulation, then it receives an appropriate compensation. Then the economic resistance to represent additional costs in the replacement circuits (Fig. 1) can be determined by the expression:

$$
\beta_{Q_{i}} Q_{i}=\frac{P_{i}^{2}+Q_{i}^{2}}{U_{i}^{2}} R_{e i}^{P Q} C .
$$

The economic resistance for the $i$-th EG, taking into account the generation of its active capacity, has the form:

$$
R_{e i}^{P Q}=\frac{U_{i}^{2}}{\left(P_{i}^{2}+Q_{i}^{2}\right)} \frac{\beta_{Q i} Q_{i}}{c} .
$$

Such representation of the economic resistance for electric power sources that can be used to generate reactive power in the EG is the most common. It allows to take into account in the optimization calculations the aggregate of active and reactive power sources, as equivalent sources (virtual power stations).

If electric stations with supports calculated according to (15) are placed in the equivalent circuits (Fig. 1), then minimization of the costs for generation of contractual reactive power will be ensured. Unlike the previous cases, both the reactive power output and the generation of electricity to the grid will be taken into account here. If, at the same time, in the EG design model, the electric grids are represented by the equivalent $r$-circuit, the energy losses in the EG are also optimized.

6.3. Efficiency estimation of the RPS distribution optimization in electric grids. To confirm the efficiency of the proposed approach to optimizing the RPS location in electric grids, calculations and field studies are performed. The aim is determination of the optimal parameters and locations for installing reactive power compensation equipment with automatic adjustment in Vinnytsia city electric grids of $10 \mathrm{kV}$. Calculations to optimize the placement of capacitor installations based on the criteria of minimum power losses and maximum return on investment are made on the basis of the described approach, which was implemented in the author's software package «LOST». The enlarged indicators are presented in Table 1.

Based on the results of the calculations, it is found that RPS location on condition that the current EG mode approaches the «ideal» one for losses, it is possible to reduce energy losses by almost $110,000 \mathrm{kWh}$ per month. This is about $10 \%$ of the total electricity losses in $10 \mathrm{kV}$ distribution grids. Taking into account the design features of individual transformer substations, technical limitations and economic factors allows to ensure the maximum return on investment. The resulting RPS distribution ensures reduction in installation, commissioning, testing and com- missioning costs by $14 \%$. Operational costs decreased by $3.5 \%$ due to a reduction in the list of substations, where provision is made for RPSs.

Table 1

Results of the analysis of efficiency of placement of reactive

\begin{tabular}{|c|c|c|c|c|c|c|}
\hline \multirow{3}{*}{$\begin{array}{c}\text { Feeding substa- } \\
\text { tions of Vinnytsia } \\
\text { city grids of } \\
10 \mathrm{kV}\end{array}$} & \multicolumn{4}{|c|}{$\begin{array}{l}\text { Reduction of electricity losses } \\
\text { during the accounting period }\end{array}$} & \multirow{2}{*}{\multicolumn{2}{|c|}{$\begin{array}{l}\text { Reducing the } \\
\text { energy saving } \\
\text { effect }\end{array}$}} \\
\hline & \multicolumn{2}{|c|}{$\begin{array}{c}\text { RPS placement for } \\
\text { minimum losses } \\
\text { (according to PLA) }\end{array}$} & \multicolumn{2}{|c|}{$\begin{array}{l}\text { RPS placement } \\
\text { for a minimum } \\
\text { payback period }\end{array}$} & & \\
\hline & $\mathrm{kW} \cdot \mathrm{h}$ & $\%$ & $\mathrm{~kW} \cdot \mathrm{h}$ & $\%$ & $\mathrm{~kW} \cdot \mathrm{h}$ & $\%$ \\
\hline «Western» & 13502 & 7.1 & 15858.8 & 8.4 & $-2356.8^{*}$ & $-17.5^{*}$ \\
\hline «Industrial» & 9042.4 & 4.7 & 8477.9 & 4.4 & 564.5 & 6.2 \\
\hline "New» & 75400.8 & 30.4 & 65944.7 & 26.6 & 9456.1 & 12.5 \\
\hline "Central» & 2721.4 & 2.5 & 0.0 & 0.0 & 2721.4 & - \\
\hline "Southern» & 4717.9 & 2.9 & 763.4 & 0.5 & 3954.5 & 83.8 \\
\hline «North» & 4946.34 & 6.8 & 5634.8 & 7.7 & -688.5* & $-13.9^{*}$ \\
\hline as a whole & 110342.0 & 10.7 & 96705.0 & 9.3 & 13637.0 & 12.4 \\
\hline
\end{tabular}
power sources in Vinnytsia city electric grids of $10 \mathrm{kV}$

Note: * for technical and economic reasons, some RPSs have been transferred from the feeder of "Central» and "Southern" substations to the substation «Western" and «North».

Thus, it has been experimentally proved that the implementation of the developed method, algorithms and software provides an effective solution to the problem of optimization of reactive energy flows and voltage levels in the distribution grids of the UES, in particular, by dispersed generation. The increase in the list of EG substations for establishing RPS does not entail an increase in complexity and deterioration in the convergence of the calculation process. This is due to the search for a decoupling from the «ideal» mode of operation, according to the principle of least action, to the optimal, taking into account active restrictions on parameters.

\section{SWOT analysis of research results}

Strengths. Application of the research results improves the speed and reliability of the solution of the problem of optimizing the placement of additional RPS in electric grids by the criterion of maximum profitability of capital investments. The effect is achieved by reducing it to a much simpler task - EG mode optimization by the criterion of minimum energy losses. The application of this approach creates prerequisites for increasing the efficiency of design solutions and, equally important, for the implementation of optimal management of reactive energy flows in the UES at the pace of the process.

Weaknesses. The main problem for the implementation of the proposed approach in the form of a computational tool is the complexity of taking into account the constraints on the dependent parameters of the EG mode. The introduction of voltage constraints at the EG nodes leads to an increase in the number of computations at individual iterations. This is due to the need to assess the impact of the RPS and additional adjustments to their economic resistance.

Opportunities. The proposed approach to optimizing the EG modes has principal advantages in the reliability of obtaining an isolation in comparison with known methods. Therefore, further research in the direction of 
improving the algorithm for recording limitations on the EG mode parameters is promising. This will increase the computational efficiency of software tools and adapt them to the requirements of operational RPS control.

Threats. The quality of the initial data on the EG parameters and modes is the determining factor for ensuring the adequacy of the results of optimization calculations. The level of equipping the majority of EGs with means of monitoring the modes is unsatisfactory. Therefore, the introduction of the developed approach to optimizing the EG distribution modes is likely to be accompanied by the costs of improving the relevant information and measurement systems.

\section{Conclusions}

1. Based on the research results, a new solution to the problem of increasing the efficiency of control of reactive power flows in EGs is obtained, which consists in developing, based on the principle of least action, a method and algorithms for optimizing the location of additional reactive power sources.

According to the results of the analysis of publications, it is established that with the change in the structure of power consumption and the DES development, the importance of improving the methods and means for optimizing the modes of electric grids of power supply companies by reactive power and voltage is growing. In addition, because of the increasing complexity of the problem, classical methods of optimization prove to be ineffective in reliability and speed.

2. The expediency of using the principle of least action to increase the reliability and speed of solving the problem of optimizing the distribution of RPS in electric grids with DESs based on the criterion of the maximum profitability of capital investments is justified. The use of the «ideal» EG mode model has made it possible to reduce the indicated problem of nonlinear optimization to the problem of finding the extreme current distribution in the interventions of the equivalent r-circuit of the grid, which is in principle simpler.

3. In order to take into account the economic factors of the problem of finding the optimal location of reactive power sources, the circuit of the «ideal» grid mode is supplemented by their economic supports. The method of determining and correcting the latter is based on comparing the additional operating costs and the cost of power losses in them. Models of economic resistance have been obtained for various sets of problems of optimization of parameters and conditions for the DESs operation in electric grids.

4. Based on the results of the full-scale experiment on the example of Vinnytsia city electric grids, it is proved that the implementation of the proposed approach provides an effective solution to the problem of optimization of reactive energy flows in distribution grids. The installation of additional RPS in these grids according to the results of optimization calculations makes it possible to obtain a reduction in electricity losses of more than $9 \%$.

\section{References}

1. Stohnii B. S., Kyrylenko O. V., Denysiuk S. P. Intelektualni elektrychni merezhi elektroenerhetychnykh system ta yikh tekhnolohichne zabezpechennia // Tekhnichna elektrodynamika. 2015. Vol. 6. P. 44-50.
2. Electric Power Research Institute Tech. Rep. The Smart Grid Interoperability Standards Roadmap. August 2009. URL: https:// www.nist.gov/sites/default/files/documents/smartgrid/Report_ to NIST August10 2.pdf

3. Pryntsyp naimenshoi dii v elektrotekhnitsi ta elektroenerhetytsi: monograph / Lezhniuk P. D. et al. Vinnytsia: UNIVERSUMVinnytsia, 2014. 212 p.

4. Kulyk V. V., Hrytsiuk I. V., Hrytsiuk Yu. V. Optymalne keruvannia potokamy reaktyvnoi potuzhnosti $\mathrm{v}$ rozpodilnykh elektromerezhakh z rozoseredzhenym heneruvanniam // Pratsi Instytutu elektrodynamiky NANU. Zbirnyk naukovykh prats. 2013. Spetsialnyi vypusk. P. 151-158.

5. Hinz F., Moest D. Techno-economic Evaluation of $110 \mathrm{kV}$ Grid Reactive Power Support for the Transmission Grid // IEEE Transactions on Power Systems. 2018. doi:10.1109/ tpwrs.2018.2816899

6. Reactive power management by distribution system operators concept and experience / Becker W. et al. // CIRED Open Access Proceedings Journal. 2017. Vol. 2017, No. 1. P. 2509-2512. doi:10.1049/oap-cired.2017.0347

7. Guidelines for distribution system operators on reactive power provision by electric vehicles in low-voltage grids / Zecchino A et al. // CIRED - Open Access Proceedings Journal. 2017. Vol. 2017, No. 1. P. 1787-1791. doi:10.1049/oap-cired.2017.0377

8. Kaloudas C., Shaw R. Long-term forecasting of reactive power demand in distribution networks // CIRED - Open Access Proceedings Journal. 2017. Vol. 2017, No. 1. P. 2406-2410. doi:10.1049/oap-cired.2017.0182

9. Zhelezko Yu. S. Kompensatsiya reaktivnoy moshhnosti v slozhnykh elektricheskikh sistemakh. Moscow: Energoizdat, 1981. 200 p.

10. Narayan S. R. Solved Nonlinear Optimization Problems // Optimization Principles: Practical Applications to the Operation and Markets of the Electric Power Industry. Wiley-IEEE Press, 2003. P. 245-295. doi:10.1109/9780470545454.ch8

11. Lezhniuk P. D., Demov O. D., Pivniuk Yu. Yu. Poetapnyi rozrakhunok kompensatsii reaktyvnoi potuzhnosti v rozpodilnykh elektrychnykh merezhakh iz vykorystanniam vidnosnykh spadiv napruhy // Visnyk Pryazovskoho derzhavnoho tekhnichnoho universytetu. Seriia: Tekhnichni nauky. 2015. Vol. 2, No. 30. P. 108-115.

12. Zhu J. Reactive Power Optimization // Optimization of Power System Operation. Wiley-IEEE Press, 2009. P. 409-454. doi:10.1002/9780470466971.ch10

13. Optimal reactive power dispatch for enhancement of static voltage stability using jaya algorithm / Singh P. et al. // 2017 International Conference on Information, Communication, Instrumentation and Control (ICICIC). Indore, 2017. doi:10.1109/icomicon.2017.8279044

14. Wong K. P., Li A., Law T. M. Y. Advanced, constrained, genetic algorithm load flow method // IEE Proceedings - Generation, Transmission and Distribution. 1999. Vol. 146, No. 6. P. 609-678. doi:10.1049/ip-gtd:19990638

15. Multi-objective reactive power optimisation approach for the isolated grid of new energy clusters connected to VSC-HVDC / Yin S. et al. // The Journal of Engineering. 2017. Vol. 2017, No. 13. P. 1024-1028. doi:10.1049/joe.2017.0484

16. Kholmskiy V. G. Optimizatsiya potokoraspredeleniya v zamknutykh elektricheskikh setyakh s vysokoy stepen'yu neodnorodnosti // Elektrichestvo. 1965. Vol. 9. P. 16-21.

17. Elektricheskie sistemy: elektricheskie raschety, programmirovanie i optimizatsiya rezhimov / ed. by Venikov V. A. Moscow: Vysshaya shkola, 1973. 320 p.

Kulyk Volodymyr, Doctor of Technical Sciences, Associate Professor Department of Electric Stations and Systems, Vinnytsia National Technical University, Ukraine, e-mail: volodymyrokulyk@gmail.com, ORCID: http://orcid.org/0000-0002-7594-5661

Burykin Oleksandr, PhD, Associate Professor, Department of Electric Stations and Systems, Vinnytsia National Technical University, Ukraine, e-mail: mr.burykin@gmail.com, ORCID: https:// orcid.org/0000-0002-0067-3630

Pirnyak Viktor, Deputy Head of Inspection of State Energy Supervision in Vinnytsia region, Separate Subdivision «State Energy Supervision in the Southwest Region» of SE «NEC «Ukrenergo», Ukraine, e-mail: vpirnyak@gmail.com,ORCID: http://orcid.org/00000003-4550-6411 